\title{
The Nasionalism Defense Value Character in Ketoprak Manuscript of Kyai Kala Gumarang
}

\author{
Anton Kurniawan', Suyitno $^{2}$ and Ani Rakhmawati ${ }^{3}$ \\ 1,2,3 Universitas Sebelas Maret, Surakarta, Indonesia \\ 19anton@student.uns.ac.id, ${ }^{2}$ yitsuyitno52@gmail.com, ${ }^{3}$ anirakhmawati@staff.uns.ac.id
}

\begin{abstract}
Ketoprak is one of Javanese arts which contains a lot of educational values. The character values contained in ketoprak, for instance, is tstate defense. This study aims to find and describe the figures that show the character of state defense in the dialogue. This research used descriptive qualitative study with Kyai Kala Gumarang as the object of the text study. After analyzing the data, the ketoprak manuscript of Kyai Kala Gumarang contained several character values of state defense shown in the dialogue of the characters. The character value of state defense is expected to be applied as the example for audiences. The character of state defense must be possessed by every citizen because this character will stimulate more loving and proud citizens towards their country.
\end{abstract}

Keywords: nasionalism defense character, ketoprak script, kyai kala gumarang

\section{INTRODUCTION}

Literature as a work of art contains beauty and relevance to human life as the creator. Literature comes with a function as a spectacle as well as guidance for the audience. In other words, literature also contributes the character values to the community. This is in accordance with Sulaksono's argument which states that literature has a functional role as a means of introducing and strengthening the unwritten values and norms adopted by the community [1]. Literature is a work in the form of fiction but provides life values that present the truths of real life. Through literature, the author can convey all the ideas, for example in the form of messages on the character education values [2].

Ketoprak manuscript is one of literature originating from Java. In ketoprak show, it commonly uses script to determine the story that will be presented in the show. Similar to ketoprak show as folk art, the manuscript of ketoprak is also a representation of social life. It is in line with Setyawan, Saddhono, and Rakhmawati stating that the manuscript of ketoprak presents the social reality in author's life [3]. Ketoprak manuscript is a Javanese literature in which Javanese literature is a creative work in form of thoughts, experiences, and life appreciations expressed aesthetically in Javanese. Ketoprak text is categorized as one of literary texts, particularly included in traditional theatrical scripts genre. Ketoprak manuscript as one type of literature displays a portrait of human social life [4].

Ketoprak is a form of folk art that is classified in traditional performing arts. Traditional performing arts itself is one of the cultural products that can contribute to the achievement of intelligence and dignified human character [5]. While surviving as traditional regional art, traditional arts also have a strategic position in maintaining Javanese language [6]. Especially for folk art, aesthetic peak is not the ultimate goal although moral values are still orientation to 
achieve [7]. Ketoprak is a traditional form of theater with the main elements of dialogue, song, and humor. Ketoprak is a traditional Javanese drama art that represents the social life of community with Javanese cultural background [8]. Dialogues between players are presented in Javanese. Players will speak and interact in Javanese according to their level and role in the play [9]. The history of ketoprak began around 1925 and was first staged by a group called the Ketoprak Krido Madyo Utomo Association from Solo or widely known as Ketoprak Lesung [10].

Many researches have discussed about ketoprak, for instance research conducted by Waluyo et al. which discusses merely on ketoprak containing moral values [11]. Research by Naiborhu and Karina discusses the development of ketoprak in North Sumatra [12]. Furthermore, research conducted by Setyawan discusses the mixing of cultures between Javanese culture and Islamic culture in ketoprak which includes aspects of story, language, costumes and makeup, and accompaniment [8]. Nevertheless, none of these studies has discussed the character of state defense in the ketoprak manuscript. Based on this notion, this research can complement previous studies that discuss ketoprak.

As one of the cultural heritages, ketoprak is powerful enough to introduce Javanese culture to the outside and is one of the faces of the nation's cultures. In the era of globalization, any form of foreign effect easily affects lifestyle, mindset, habits, customs, and moral [13]. This is consistent with Sutardjo's opinion which states that by preserving and develop their cultural heritage, can strengthen personality, strengthen self-confidence which brings fondness of the motherland and nation, also self-confidence as the power of development [14]. Lisbijanto also supports that ketoprak is folk art that tells about life stories in ancient kingdoms, which have become legendary stories and existed in communities with the background of Javanese kingdom in the past [9].

Ketoprak as one part of Javanese culture contains stories relating to humans with various problems, norms, and regulations that bind them. This is in accordance with Surtantini's opinion which states that all activities related to art are the property of every human being and everything that is reflected in art also tells about humans [15]. Ketoprak will always contain the values of struggle, where one figure struggles to defend the country and region. The struggle in ketoprak stories may in the form of war, as well as the actions of the characters. The struggle of characters is an example of patriotism. In this study, the character value of the state defense contained in the text will be further discussed. The character of the state defense itself is one of the implementations of the 18 pillars of character education values.

\section{METHOD}

This research is descriptive qualitative research. The main focus is to describe and explain in-depth the content of character value of state defense in the text of Kyai Kala Gumarang. Descriptive research in qualitative research case studies leads to detailed descriptions and indepth portraits of the real event in the field of study [16]. The main data source in this study was the Ketoprak manuscript entitled Kyai Kala Gumarang. Data collection techniques used observation and interview techniques with ketoprak audience in Surakarta. Triangulation techniques used were data source triangulation and theory triangulation. Data analysis techniques applied analysis techniques with stages of data reduction, data presentation, and drawing conclusions [17]. 


\section{RESULT AND DISCUSSION}

\subsection{Glimpse of Kyai Kala Gumarang manuscript}

Kyai Kala Gumarang manuscript is a ketoprak manuscript by Trisno Santosa written in 2014. This manuscript is also called Bedah Mediun manuscript because the story tells about events in the Madiun region of East Java. The main story of Kyai Kala Gumarang manuscript is about the conquest of Madiun region by Metaram kingdom, led by Panembahan Senopati. In the beginning, Metaram's efforts always failed because lost they bore in every battle. In the end, Metaram sent a woman named Adisara to send false news to Madiun leader. The false news made the officials in Madiun decided to return to their respective regions, and thus Madiun defense center was weakened. When the Madiun defense was depleted due to officials leaving, the Mataram troops began to attack and eventually succeeded in conquering Madiun.

\subsection{The character value of nasionalism defense in Kyai Kala Gumarang manuscript}

The Kyai Kala Gumarang manuscript contains several character values of state defense which are reflected throughout the dialogues of the characters. The following is analysis of figures that reflect the character of the state defense:

\section{- Adisara}

Adisara was a concubine of Panembahan Senopati. The character value of state defense she showed in her dialogue when she was entrusted with a task as shown in the following excerpt.

"Kanjeng, sabda sampeyan dalem menika kukum tumrap negari, mangka kula menika kawula ing Metaram, anteping manah pejah gesang kawula, kula udhokaken kangge nambak kaluhuraning kawibawan Metaram kanjeng."

Translation:

"Your Majesty, your orders are laws and I am Metaram people, live or die I will give my soul to serve your majesty of Metaram."

Adisara's dialogue implies that king's order was the law of the country and as people of Metaram, she was ready to give her life to bring honor to Metaram kingdom. This shows quality attitude of Adisara figure who willingly gave her soul to defend her country.

\section{- Rangga Keniten}

Rangga Keniten was a Duke of Mediun. He showed his attitude to defend Mediun region when Metaram soldiers would set foot in Mediun. This is shown in the following excerpt.

"Hahah ha ha, cetha yen iki wong Metaram sing gawene mung kempros nggedobos ora ana nyatane, kena kowe-kowe kabeh ngidak bumi Mediun waton bisa nglangkahi bangkene Rangga Keniten."

Translation:

"Hahah ha ha, these people must be Metaram, full of bluffing, you all can walk on Mediun land if you can step over my body, Rangga Keniten."

From the dialogue of Rangga Keniten, it appears that he was exceptionally brave by blockading Metaram soldiers from going to the Mediun area. Moreover, he said that if they wanted to walk on Mediun, Metaram soldiers had to step over the Rangga Keniten's dead body. 


\section{- Abdi 2}

Servant 2 was a war soldier. When he was sent to find entertainment for kingdom, he showed the character of state defense through the following citation.

"Lho nek aku ngono, nek lunga ya sisan ning nek wis mulih ya sing suwe, mula aku pilih ora mulih dhisik suk emben nek genah wis aman karuane, nadyan sakiki ya ming turu ngebrak ngeloni tumbak, nyekeli keris, nyengklang pedhang. Ning nek ana aba sak wayahwayah gari mangkat mak brabat."

Translation:

"Well, If it were me, once I set off, I must do so. But once I went home, it would take a long time. So, I choose to stay and make sure everything is safe, even I have to sleep with spear, hold a dagger, carry a sword. I am ready to leave at any time."

The dialogue shows that servant 2 was willing to leave for a long time and did not return until it was safe. Even though he had to sleep everywhere available with weapons beside him, he prepared any time. This shows loyalty to Mediun region by putting obligations above everything as a soldier rather than coming home while it was dangerous.

\section{- Retno Dumilah}

Retno Dumilah is the daughter of the duke in Madiun named Rangga Jumena. Retno Dumilah showed the character value of state defense when Madiun was attacked by Metaram. As shown by the following dialogue.

"Rama mugi wonten kepareng ndalem, kula badhe majeng wonten palagan."

Translation:

"Father, may you bless, I wish to go to the battlefield."

Retno Dumilah showed a purpose that she wanted to enter the battlefield with her father's blessing. It was done to defend her homeland. The statement was supported by the following dialogue.

"Inggih rama, kula rumaos gadhah wajib mbelani tanah wutah kula."

Translation:

"Yes father, I think I have the obligation to defend my homeland."

As well as the following dialogue:

"Piyandel kula tekad, saha santosaning manah ndepani bumi Madiun rama."

Translation:

"My strength is determination and willingness to defend your Madiun land, father."

From those excerpts, Retno Dumilah asserted that she had the obligation to defend her homeland even though determination was the only power she had to defend Mediun.

\section{- Panembahan Senopati}

Panembahan Senopati was a king from the Metaram kingdom. Panembahan Senopati showed his state defense when he encountered Retno Dumilah during the war between Metaram and Mediun. The following is an excerpt from the dialogue of Panembahan Senopati.

"Bener wong ayu.. dhiajeng Retno Dumilah, apa paedahe lan pigunane perang, kang pamrihe amung rebut kamukten. Ayo nimas padha nyawiji manunggalake bumi Nuswantara ing pangajab bisaa dadi negara agung kang adil lan warata."

Translation:

"Yes, it is ... dear Retno Dumilah, what's good war has brought unless for glory. Come on dear, together we unite this nation to becoming welfare and justice country." 
From the excerpt, Panembahan Senopati invited Retno Dumilah to make peace. He uttered that war brought no good indeed unless for mere glory. Panembahan Senopati invited Retno Dumilah to unite the nation to become welfare and justice country.

Based on the analysis, there is a value of the character of the state defense in ketoprak text which shows the attitude of the figure who wants to defend and protect country from threats and also to show fondness for the country. This attitude is necessary for everyone to protect from any form of rebellion. The findings in this study can complement research on ketoprak especially researches that discuss the character values in ketoprak manuscript. One of the closely related studies is the research conducted by Waluyo, Said, and Kurwidaria which explain that there are various character building values in ketoprak [10]. Other related research is the research conducted by Waluyo et al. which analyzes the character education in ketoprak manuscript which can be seen from the attitudes and character of the characters in ketoprak manuscript [11] [18].

\section{CONCLUSION}

Ketoprak is an art that contains many character education values including state defense character. The character of state defense is an attitude in which one has nationalism and patriotism. The character of state defense must be possessed by every citizen to bring fondness towards country. The Ketoprak manuscript of Kyai Kala Gumarang, a manuscript written by an artist who is also a lecturer of the Indonesian Institute of Art named Trisno Santosa, contains character values of state defense that can be applied as learning for readers and audience of the performance. Ketoprak manuscript shows the reflection of Kyai Kala Gumarang's state defense character values in the dialogue of the characters. It is expected that the character value of state defense can be widely practiced as the example so that we can grow our fondness toward our country as good citizens to become welfare and justice country.

\section{REFERENCES}

[1] U. Chafidhi, W. Abdullah, and D. Purnanto, "Local Wisdom in Javanese Language and Culture expressed by the Javanese Coastal Community of Banjar Kemuning Village of Sidoarjo (An Ethnolinguistic Study)," in Fifth Prasasti International Seminar on Linguistics (PRASASTI 2019), 2019.

[2] E. Suryanto, "Pengembangan Materi Ajar Mata Kuliah Apresiasi Drama Melalui Penggalian Nilai-nilai Pendidikan Karakter Naskah Drama Panembahan Reso Karya W.S. Rendra," Bhs. dan Seni J. Bahasa, Sastra, Seni, dan Pengajarannya, vol. 44, no. 2, pp. 207-223, 2017.

[3] B. W. Setyawan, K. Saddhono, and A. Rakhmawati, "Sociological Aspects and Local Specificity in the Classical Ketoprak Script of Surakarta Style," J. Lang. Lit., vol. 17, no. 2, pp. 144-151, 2017.

[4] B. W. Setyawan, K. Saddhono, and A. Rakhmawati, "Potrait of Javanese Society Condition on Classcial Ketoprak Script of Surakarta Style," Aksara, vol. 30, no. 2, pp. 205-220, 2018.

[5] A. Setiawan, "Problematika Seni pertunjukan Tradisi di Sekolah," Didakt. J. Pendidik. dan Ilmu Pengetah., vol. 15, no. 1, pp. 88-102, 2015.

[6] Y. S. Amin, H. B. Mardikantoro, and A. Syaifudin, "Pemertahanan Bahasa Jawa dalam Kesenian Kuda Lumping di Banjarnegara,” J. Sastra Indones., vol. 6, no. 1, pp. 1-6, 
2017.

[7] R. Lanjari, "Political Practice and Its Implication on Folk Art Marginalization (Case Study of Wayang Orang/Human Puppet Ngesti Pandhowo)," Harmon. J. Arts Res. Educ., vol. 16, no. 2, pp. 163-171, 2016.

[8] B. W. Setyawan, "Akulturasi Budaya Islam-Jawa dalam Pementasan Kesenian Ketoprak," Danc. Theatr. Rev. J. Tari, Teater, dan Wayang, vol. 2, no. 1, pp. 25-34, 2019.

[9] H. Lisbijanto, Ketoprak. Yogyakarta: Graha Ilmu, 2013.

[10] B. Waluyo, D. Said, and F. Kurwidaria, "Ketoprak, Cultural Heritage, and Character Building," in Proceedings of the Proceedings of the 1st Seminar and Workshop on Research Design, for Education, Social Science, Arts, and Humanities, SEWORD FRESSH 2019, April 27 2019, Surakarta, Central Java, Indonesia, 2019.

[11] B. Waluyo, F. Kurwidaria, A. A. Rahadini, D. P. Said, and B. W. Setyawan, "Peran Naskah Ketoprak Sebagai Salah Satu Sarana Menanamkan Budi Pekerti di Kalangan Mahasiswa," in SEMINAR NASIONAL BAHASA, SASTRA DAERAH, DAN PEMBELAJARANNYA 2018, 2018, pp. 34-44.

[12] T. Naiborhu and N. Karina, "Ketoprak, Seni Pertunjukan Tradisional Jawa di Sumatera Utara: Pengembangan dan Keberlanjutannya," Panggung, vol. 28, no. 4, pp. 482-497, 2018.

[13] F. S. Fujiawati, R. Permana, D. J. Lestari, and G. M. Roekmana, "Implementasi Model Pembelajaran Seni Terpadu untuk Meningkatkan Apresiasi dan Kreativitas Seni Budaya Tradisional Daerah Banten “Teater Rakyat Ubrug",” JPKS (Jurnal Pendidik. dan Kaji. Seni), vol. 2, no. 1, pp. 51-62, 2017.

[14] I. Sutardjo, Kajian Budaya Jawa. Surakarta: Jurusan Sastra Daerah, Fakultas Sastra dan Seni Rupa, Universitas Sebelas Maret, 2008.

[15] R. Surtantini, "Pembelajaran Seni Bahasa dalam Konteks Lintas Kurikulum melalui Drama," J. Kaji. Seni, vol. 2, no. 1, pp. 68-77, 2015.

[16] S. J. Gentles, C. Charles, J. Ploeg, and K. McKibbon, "Sampling in Qualitative Research: Insights from an Overview of the Methods Literature," Qual. Rep., vol. 20, no. 11, pp. 1772-1789, 2015.

[17] J. Harding, Qualitative data analysis: From start to finish. Singapore: SAGE Publications Limited, 2018.

[18] K. Saddhono and S. Supeni. "The role of dutch colonialism in the political life of Mataram dynasty: A case study of the manuscript of Babad Tanah Jawi." Asian Soc. Sci. vol. 10 no. 15 pp. 1-7, 2014 